\title{
(Re) criação e inovação do cuidado de enfermagem
}

\author{
Regina Maria dos Santos', Lenira Maria Wanderley Santos de Almeida', \\ Maria Cristina Soares Figueiredo Trezza" \\ ' Coordenação da Comissão Executiva do $63^{\circ}$ Congresso Brasileiro de Enfermagem. \\ ABEn Seção Alagoas. Maceió-AL, Brasil. \\ " Coordenação da Subcomissão de Temas do $63^{\circ}$ Congresso Brasileiro de Enfermagem. \\ ABEn Seção Alagoas. Maceió-AL, Brasil.
}

No período de 3 a 6 de outubro de 2011, realizou-se, em Maceió-AL, o $63^{\circ}$ Congresso Brasileiro de Enfermagem (CBEn). O evento teve como tema central a (Re) criação e inovação do cuidado de enfermagem, com o qual se deu continuidade ao propósito da Associação Brasileira de Enfermagem de transformar o maior evento científico-cultural e político da Enfermagem brasileira em espaço privilegiado de articulação, pactuação e atualização para profissionais de Enfermagem, associados ou não à entidade.

Durante o evento, discutimos e estudamos, criticamente, como podemos (re) inventar o nosso trabalho de cuidar das pessoas, para torná-lo qualificado, cientificamente embasado, e logicamente arquitetado, planejado, organizado e financiado, para produzir efeitos úteis às pessoas, famílias ou coletividades humanas, em seu contexto de vida, tornando-as capazes de lutar pela promoção, proteção e recuperação de sua saúde, no plano individual e coletivo. Oportunizando espaços de aprendizado e de discussão de possibilidades para a sustentabilidade profissional, a programação articulou os cinco eixos que compõem o trabalho da Enfermagem: a assistência, a gestão e o gerenciamento, a educação, a investigação e a atividade associativa. Congressistas, palestrantes e autoridades, juntos, teceram o rico bordado de uma rede de compromissos, atualizações e parcerias que, fortalecidos e consolidados, sustentarão os projetos para o futuro da profissão, e servirão como base para propostas institucionais que reflitam os anseios dos profissionais e a atenção aos usuários do Sistema Único de Saúde (SUS).

Constituir-se como a maior força de trabalho no campo da saúde, e com a responsabilidade de executar em torno de $70 \%$ das ações de saúde, nos coloca diante dos desafios de contribuir decisivamente para a efetivação do SUS, e de providenciar a qualificação constante do nosso saber/fazer. Coloca-nos, ainda, diante dos desafios de exercer o controle social e de exigir dos poderes constituídos os direitos correspondentes às nossas responsabilidades, os quais se expressam na luta por condições de trabalho dignas e por salários justos e condizentes com a nossa importância; e por uma jornada de trabalho compatível com a responsabilidade de quem cuida de vidas e, portanto, precisa cuidar-se, para cuidar sem oferecer risco para si e para a pessoa cuidada.

Sustentando sua prática em evidências científicas e em valores éticos e estéticos, a luta da Enfermagem é pelo cuidado universal, integral e equânime. Por esta razão é que discutimos, profundamente, a (re)criação do cuidado de Enfermagem, um cuidado que não pode se afastar nem do conhecimento contemporâneo, nem dos princípios éticos universais, e que precisa respeitar valores morais e legais. Nesta condição, estamos em posição propícia para demandar a consolidação de uma agenda de compromissos com os poderes constituídos, para resolver os graves problemas que enfrentamos na conjuntura atual; e que considere e respeite a Enfermagem como a parceira que é na efetivação do SUS.

Conclamamos aos que aqui chegaram a se manterem engajados em torno de nossas entidades e órgão de classe, em um movimento de cidadania ativa, fundamentada nos valores que alicerçam a profissão, e de fortalecimento das nossas representações profissionais, para avançarmos em nossas lutas e conquistas específicas, e em defesa das bandeiras de luta no campo social. 